\title{
The Effects of Financial Constraints on Investments in Korean Stock Market
}

\author{
Shinae KANG \\ Associate Professor, National University of Science and Technology, Seoul, Korea. \\ E-mail: sakang@seoultech.ac.kr
}

Received: November 19, 2019. Revised: December 21, 2019. Accepted: December 24, 2019.

\begin{abstract}
Purpose - This paper empirically investigates what factors contribute to corporate investments under financial constraint condition in the Korean stock market. In the paper, tangible assets' growth rate and fixed assets' growth rate were employed as investment performance and total assets were also used for comparison purpose.

Research design and methodology - Samples are constructed by manufacturing firms listed on the stock market of Korea as well as those who settle accounts in December from 2001 to 2018. Financial institutions are excluded from the sample as their accounting procedures, governance and regulations differ. This study adopted a fixed panel regression model to assess the sample construction including yearly and cross-sectional data.

Results - This results support the literatures that major shareholders showed positive significance to investment in financially unconstrained firms and no significance to investment in financially constrained firms. ROA showed positive significance to investment in financially unconstrained and constrained firms, whereas firm size showed negative significance to investment in financially unconstrained and constrained firms. Debt showed no positive significance to investment in financially unconstrained firms and negative significance to investment in financially constrained firms.

Conclusions - This paper documented evidence that ROA and firm size are important factors to investment irrespective of firms' financial constraints. And this paper also supports that major shareholders give positive impact to investments in financially unconstrained firms. This means that financial constraints itself rule corporate' investment decision in financially constrained firms.
\end{abstract}

Keywords: Financial constraints, Major shareholders, Tangible asset, Fixed asset, KZ index

JEL Classification Code: G3, M1. 


\section{Introduction}

Consumer Leading Indicators (hereafter CLIs) published by OECD ${ }^{1}$ show downward trends from 2018 to 2019. Along with downward trends in CLIs, trade friction between US and China has deepened, leading high uncertainty for global economy. Figure 1 also shows that Korea's economy is also expected to slow down.

Figure 1: OECD Consumer Leading Indicator

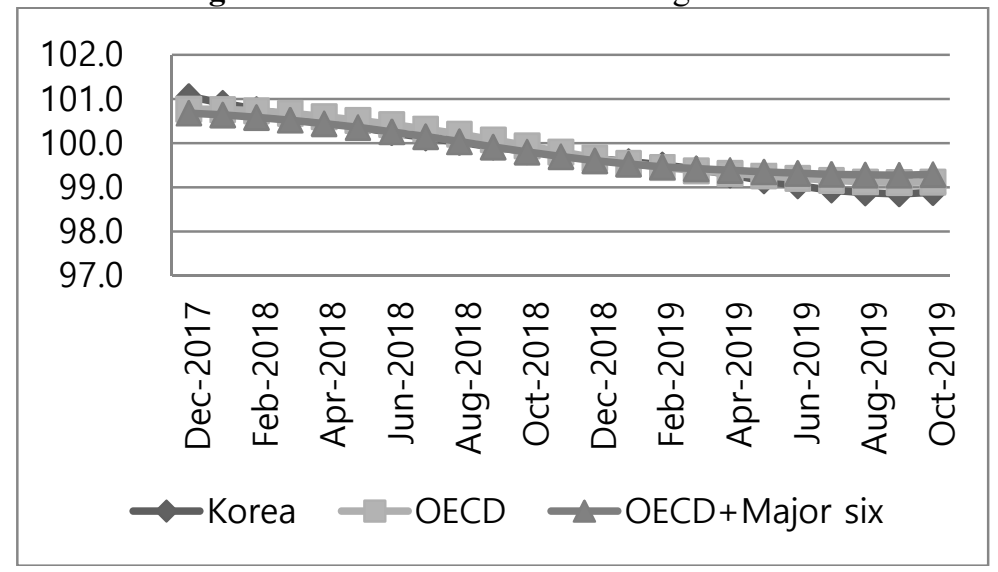

Note: Source OECD.stat

As an economic recession is expected, investment decisions are expected to be tightly controlled by top management teams. If a firm's financial constraint is more than other companies, then factors affecting the firm's investment decision may be different from financially unconstrained firms. Ra and Lee (2012) said that financial constraint hypothesis is important hypothesis under the situation of environmental uncertainty. Kang (2019) documented evidence that financial constrained firms use dividends for their investment and foreign investors decrease investments under financial constraints. But for dividends decisions, foreign investors give significant positive impacts irrespective of financial constraints.

This study attempts to analyze the relationship between financial constraints and investments for firms listed on the Korea Stock Exchange's securities whose closing month is December from 2001 to 2018 by applying panel regression. The differentiation from prior research is as follows. Compared to previous studies covering firms' investment decision for manufacturing companies, this study deals investments with financial constraints that relatively little research have been done.

The rest of the study is carried out as follows. Chapter 2 looks at the previous literatures of investments and financial constraints. Chapter 3 deals with samples and methodology. Chapter 4 describes the results of the empirical results. Chapter 5 presents conclusions and implications.

\section{Literature Review}

Ihm, Sohn, and Kam (2011) studied that the purpose of manufacturing businesses listed on the nation's trading market from 1981-2009 is to be verified and verified how cash reserves under the financial statements are affecting the value and investment of companies. All companies were analyzed by dividing them into financial and nonfinancial companies based on financial constraints. The analysis results show that, first of all, in cash reserves, financially constrained companies had higher average and median values than financial non-pharmaceutical firms on

\footnotetext{
${ }^{1}$ CLIs are calculated for 33 OECD countries (Iceland is not included), 6 non-member economies and 8 zone aggregates. A
} country CLI comprises a set of component series selected from a wide range of key short-term economic indicators. 
all financial constraints. In addition, the average value of the cash holding standard deviation and the standard deviation of the cash fluctuation was relatively greater for financially constrained companies than for financial unconstrained companies. This empirical analysis shows evidence that financially constrained companies hold more cash reserves than financial unconstrained companies. Second, the relationship between cash holdings and entrepreneurship has shown significantly positive $(+)$ relationship, so the higher the cash reserves, the higher the value of the company. It can be seen that the above results are consistent previous literature. Third, the relationship between cash holdings and investments did not appear to be significant, unlike previous studies that showed that more cash reserves meant more investment. Finally, some financially constrained firms had little or no cash reserves, even though they had many benefits from having sufficient cash reserves. This could not be explained by incentive problems, by over-investing agent costs or by low outside procurement costs, and the reason for the weak financial health of the company itself was because of its own.

Shin, Kim, and Lee (2013) conducted an empirical analysis of the effect of financial constraints on cash limits on companies listed on the Korea Exchange's securities market and KOSDAQ market from January 1, 2001 to December 31, 2011, and the main analysis results were as follows. Shareholders value the limit value of cash held by a company lower than the cash held personally by them. This is because the limit value of cash held by a company is assessed on a post-tax basis. Shareholders also value the higher the existing cash level held by the company, the lower the cash limit will be. These results are consistent with the argument that excess cash may impair shareholder value, discipline the company in which shareholders have excess cash in the capital market, and that excess cash may significantly increase agency costs. Shareholders value lower cash limit because the higher the existing leverage, the higher the portion of value added generated in cash paid to the creditors as interest expense. The higher the stock buyback ratio, the lower the dividend income tax rate due to the cash dividend, the lower the individual income tax. Therefore shareholders value the limit value of cash held by a company higher than the ratio of its share buyback. In addition, shareholders rate the cash limit held by financial weak companies higher than that held by financially unconstrained companies. In other words, financially constrained companies with low capital market access or a low credit rating value cash held within the company because it is difficult and more costly to procure investors from the capital market. These results suggest that shareholders in the capital market discipline companies that have excessive amounts of cash or overuse of leverage, consistent with the agency theory that such companies could undermine shareholder value. More importantly, financially constrained companies' value cash limits higher than unconstrained firms. Thus under financial constraints, a company's managers can preserve its shareholder value by maintaining the cash limit through proper cash reserves.

Han and Jeong (2013) aims to present an integrated model of investment decision and ship operation decision under financial constraints from the perspective of maximizing economic added value during the planned period for shipping companies operating container and bulk business. First, considering the characteristics of customer demand by business unit, an investment decision model was established to reflect the decision of ship operation to allocate ships, the purchase and sale of ships for each period, and the dragon boat and the presidential election. Furthermore, an enterprise-wide integrated model reflecting financial constraints is proposed so that decisions on operations and investments by business units can be considered under the constraints of the company's overall budget and resources.

Nam and Park (2015) seeks to investigate the impact of financial market shocks on corporate cash reserves and R\&D sustainability in order to verify the impact of the U.S.-originated global financial crisis on the Korean market among a number of major factors affecting R\&D sustainability. Specifically, the effect of cash reserves on R\&D sustainability of the company is analyzed and then the impact of the financial market on the relevance between the company's cash reserves and its R\&D sustainability is explored. In addition, the focus was on verifying the effectiveness of market shocks on cash reserves after classifying them as financial-constrained entities and those that did not. For analysis, 390 listed companies were selected using the financial statements disclosed in the last 14 years from 2000 to 2013, and 4,428 observations were used. Using this data, the research theory was set up to find determinants for R\&D persistence of financially constrained companies and panel data analysis using fixed effect models was conducted based on time series data. The analysis showed that cash reserves of young companies with severe financial constraints had a significant inverse (-) relationship to R\&D sustainability, and that the impact of financial markets on financially constrained companies had an adjustment effect between cash reserves and R\&D 
sustainability. This study presented a link between corporate cash reserves and financial markets shock that was not considered in a study on the relevance between existing cash reserves and R\&D sustainability, and further found that market shocks were actually having a strong effect between financially constrained companies' cash reserves and R\&D sustainability.

Lee and Kim (2017) analyzed the relationship between financial constraints and price-earnings ratios in the domestic stock market. In foreign literature, a considerable number of studies have been conducted on the effect of financial constraints on stock returns, but no consensus has been reached. There is no empirical study in Korea that reveals the relationship between financial constraints and stock returns. In response, this study empirically analyzed the perception of risk factors that financial constraints are systematically reflected in stock prices in the domestic stock market. The analysis showed that the stronger the financial constraints of the company in the domestic stock market, the higher the future share price, and the difference in returns between those with strong financial constraints and those with weak financial constraints showed a statistically significant relationship. In particular, an analysis of the market boom phase and the market downturn through the return of the KOSPI in the past shows that the difference in returns between companies with strong financial constraints in terms of market boom and weak companies shows a statistically significant value. A review of the excess return on the CAPM and the Fama-French 3 -factor models explained the difference between the portfolio with the strongest financial constraints and the monthly average return on the portfolio with the weakest financial constraints is not explained by the CAPM, but by the model with the Fama-French 3-factor. Therefore, it has been shown that financial constraints are not a new risk factor that differs from existing risk factors.

Lee and Byun (2017) demonstrated whether financial statements play a disciplinary role in cash use because of agency problem. In the event of a financial arrangement that is rich in current cash reserves but difficult to raise outside funds, the management who values private benefit will be unlikely to use cash in the negative net present value investment under a financial constraints situation. They verified that the management performance after cash use is related to investment opportunities. The results showed that cash use by financially unconstrained firms was linked to a higher future performance compared to that of non-financial firms, and that the positive effects of these financial statements were not attributed to differences in corporate governance. Moreover, financial statements are considered to play a substantial role in disciplining managers as a substitute for good corporate governance. Good corporate governance increases the efficiency of cash use in financially unconstrained companies, but does not affect financially constrained companies. Similarly, the regulatory impact of financial statements was found to be concentrated in companies with weak governance structures.

\section{Sample and Methodology}

The sample cover firms whose settlement is December among retail companies listed on the Korea Stock Exchange's securities market and KOSDAQ market from 2001 to 2018. Manufacturing firms were used and of these the targets were companies with operating profit and equity capital of zero or higher and with sales data. The financial data was collected through KIS-VALUE. There may exist the effects of extreme values, so winsorizing was used to independent variables and those variables were censored at the top and bottom $1 \%$.

For financially constraints, we follow Ra and Lee (2012)'s method. Ra and Lee (2012) use KZ index as financially constraints, which used excess free cashflows, tobinQ, leverage, dividends and cash holdings. After constructing $\mathrm{KZ}$ index, companies were categorized as good when their $\mathrm{KZ}$ index belonged to lower $30 \%$ and as bad when their KZ index belonged to upper $30 \%$. And companies were reclassified as 1 if their $\mathrm{KZ}$ index was good at time $\mathrm{t}-1$ and $\mathrm{t}$ and as 2 if their $\mathrm{KZ}$ index was bad at time $\mathrm{t}-1$ and $\mathrm{t}$. In panel regression, we used companies categorized as 1 and 3 as financially unconstrained and constrained companies.

For dependent variables, four variables were used as investment variables: tangible assets growth rate (Tgbg), fixed assets growth rate (Fixg), tangible assets growth over total assets (Tgbt), and fixed assets growth over total assets (Fixt). For the independent variables, the variables related to a firm's earnings management were selected by 
referring to the preceding studies. Muhammad, Rehman, and Waqas (2016) concluded that corporate governance practices affect the firm performance. Therefore they suggested that managers should understand the governance mechanisms to work more efficiently in the firm. Higher quality of corporate governance and transparency in corporate governance is important (Rahman and Khatun, 2017; Ruonan \& Hong, 2019). And Shao, Zhang and Yu (2017) found the positive relationship on Chinese-listed firms with a panel VAR approach. So shares of major shareholders' were included as a dependent variable. There exits positive relationship between profitability and distance to default (Vu, Do, Dang and Nguyen, 2019). Lau and Mahat (2019) suggested that firms should manage cash flow prudently in considerations of firm value from the shareholder's perspective, measured directly using stock return. So Roa is included as a profitability variable. Yijayakumaran and Vijayakumaran (2019) found a negative relationship between growth opportunities and leverage. So Debt included as a leverage variable. Zhang and Yin (2018) found that enterprise heterogeneity namely firm size, nature of property right, and institutional environment reflected by the level of regional financial development indirectly affects corporate investment efficiency by influencing the financing constraints and uncertainty. So Size included as a firm size variable. $<$ Table $1>$ provides definitions of the main variables in this study.

Table 1: Description of Variables

\begin{tabular}{|c|c|c|}
\hline \multirow{4}{*}{ Dependent variable } & Tgbg & (Tangible assets $(\mathrm{t})-$ Tangible assets $(\mathrm{t}-1)) /$ Tangible assets $(\mathrm{t}-1)$ \\
\hline & Fixg & $($ Fixed $\operatorname{assets}(\mathrm{t})$-Fixed $\operatorname{assets}(\mathrm{t}-1)) /$ Fixed $\operatorname{assets}(\mathrm{t}-1)$ \\
\hline & Tgbt & $($ Tangible assets $(\mathrm{t})$-Tangible assets(t-1))/Total assets(t-1) \\
\hline & Fixt & $($ Fixed $\operatorname{assets}(\mathrm{t})-$ Fixed $\operatorname{assets}(\mathrm{t}-1)) /$ Total $\operatorname{assets}(\mathrm{t}-1)$ \\
\hline \multirow{7}{*}{ Independent variable } & Fixt & $($ Fixed $\operatorname{assets}(\mathrm{t})-$ Fixed $\operatorname{assets}(\mathrm{t}-1)) /$ Total $\operatorname{assets}(\mathrm{t}-1)$ \\
\hline & M & the ownership ratio of majority shareholders and affiliated parties \\
\hline & Roa & (net income / total asset) \\
\hline & Div & cash dividends / net income \\
\hline & Debt & total liabilities / total asset \\
\hline & Std & standard deviation of the operating income for the past three years \\
\hline & Size & $\log$ (total asset) \\
\hline
\end{tabular}

\section{Empirical Results}

\subsection{Summary Statistics and Correlations}

A summary statistic for the dependent and independent variables is given in $<$ table2 $>$. The average (standard deviation) of the tangible assets growth rate (Tgbg) and fixed assets growth rate (Fixg) estimated is 0.114 (0.232) and $0.142(0.229)$, the tangible assets growth over total assets (Tgbt) and fixed assets growth over total assets (Fixt) estimated is $0.0109(7.408)$ and $0.160(8.922)$. The correlation between tangible assets growth rate and fixed assets growth rate is 0.7335 , but correlations other investment variables are relatively low like tangible assets growth rate (Tgbg) and tangible assets growth over total assets (Tgbt). The average (standard deviation) of Roa is 0.024(0.234) and for major shareholders, 41.719(16.317). The correlation coefficient between the major variables is also given in Table 2. Roa, dividend and standard deviation of operating income (Std) have a positive relationship with investment variables. Debt and company size have a negative relationship with investment variables. 
Table 2: Descriptive statistics

\begin{tabular}{|c|c|c|c|c|c|c|c|c|c|c|c|c|}
\hline & Mean & $\begin{array}{l}\text { Std. } \\
\text { Dev. }\end{array}$ & (1) & (2) & (3) & (4) & (5) & (6) & (7) & (8) & (9) & (10) \\
\hline $\begin{array}{c}\text { (1) } \\
\text { Tgbg }\end{array}$ & 0.114 & 0.232 & 1 & & & & & & & & & \\
\hline (2) Fixg & 0.142 & 0.229 & $0.7335^{*}$ & 1 & & & & & & & & \\
\hline (3) Tgbt & 0.109 & 7.408 & $0.0345^{*}$ & $0.0314 *$ & 1 & & & & & & & \\
\hline (4) Fixt & 0.160 & 8.922 & $0.0336^{*}$ & $0.0378^{*}$ & $0.9997^{*}$ & 1 & & & & & & \\
\hline (5) Roa & 0.024 & 0.234 & $0.1268^{*}$ & $0.1327^{*}$ & $-0.0462 *$ & $-0.0482 *$ & 1 & & & & & \\
\hline (6) $\mathrm{M}$ & 41.719 & 16.317 & -0.0098 & -0.01 & -0.0136 & -0.0166 & $0.1409^{*}$ & 1 & & & & \\
\hline (7) Div & 0.009 & 0.012 & $0.1198 *$ & $0.1384 *$ & 0.0058 & 0.0051 & $0.3410 *$ & $0.1397^{*}$ & 1 & & & \\
\hline (8) Debt & 1.226 & 1.461 & $-0.0188^{*}$ & $-0.0423 *$ & -0.006 & -0.0062 & $-0.1120^{*}$ & $-0.0537^{*}$ & $-0.2668^{*}$ & 1 & & \\
\hline (9) Std & 0.116 & 0.342 & $0.0978^{*}$ & $0.1008^{*}$ & $0.0225^{*}$ & $0.0252 *$ & $-0.1390 *$ & $-0.1258^{*}$ & $-0.0881^{*}$ & $0.0497 *$ & 1 & \\
\hline $\begin{array}{l}\text { (10) } \\
\text { Size }\end{array}$ & 26.293 & 1.439 & $-0.0640 *$ & $-0.0809^{*}$ & $-0.0232 *$ & $-0.0234 *$ & $0.0665^{*}$ & -0.04 & 0.0205 & $0.0258^{*}$ & $-0.0678^{*}$ & 1 \\
\hline
\end{tabular}

Note1 :*Significant at 5\%

\subsection{Regression results}

$<$ Table $3>$ summarizes the results of the la e, regression analysis to look at the effect financial constraints on the firms' investment decision. Model (1) through model (3) use growth rate of tangible assets and model (4) through model (6) use growth rate of fixed assets. From model (1) through model (6), the empirical analysis showed significant positive effects in the relationship between firms' ROA and firms' investment and significant negative effects in the relationship between firm size and firms' investment. So irrespective of firm's financial constraints conditions, profitability (ROA) and firm size are important factor for firm's investment.

Model (2) and model (5) show that major shareholders give significant positive impact on firm's investment, which support the literature that in financially constrained firms, financial constraints itself rule company, but in financially unconstrained firms, corporate mechanism controls investment decisions(Ra and Lee, 2012). Model (3) and model (6) show positive negative impact of debt to investments. This shows that firms cannot invest more under financially constrained condition.

Table3: Test of the Relationship between Financial Constraints and Investment I

\begin{tabular}{|c|c|c|c|c|c|c|}
\hline Model & (1) & (2) & (3) & (4) & $(5)$ & (6) \\
\hline $\begin{array}{l}\text { Dependent } \\
\text { variable }\end{array}$ & \multicolumn{3}{|c|}{ Growth rate of Tangible Assets } & \multicolumn{3}{|c|}{ Growth rate of Fixed Assets } \\
\hline sample & All & Unconstrained & Constrained & All & Unconstrained & Constrained \\
\hline \multirow{2}{*}{ M } & 0.000 & $0.001 *$ & 0.000 & 0.000 & $0.001 *$ & 0.000 \\
\hline & 0.427 & 1.793 & 0.618 & 1.243 & 1.905 & 0.732 \\
\hline \multirow{2}{*}{ Roa } & $0.203 * * *$ & $0.090 * *$ & $0.611 * * *$ & $0.243 * * *$ & $0.116^{* * *}$ & $0.771 * * *$ \\
\hline & 6.895 & 2.224 & 5.703 & 8.444 & 2.996 & 6.818 \\
\hline Div & $1.738 * * *$ & $8.528 * * *$ & $1.381 * *$ & $2.130 * * *$ & $12.135 * * *$ & 1.025 \\
\hline
\end{tabular}




\begin{tabular}{ccccccc} 
& 4.821 & 2.823 & 2.292 & 6.032 & 4.221 & 1.612 \\
Debt & $-0.007^{* *}$ & -0.002 & -0.063 & $-0.013^{* * *}$ & -0.005 & $-0.115^{* * *}$ \\
& -2.430 & -0.455 & -1.611 & -4.538 & -1.398 & -2.760 \\
Std & $0.112^{* * *}$ & -0.034 & 0.012 & $0.094^{* * *}$ & -0.059 & 0.203 \\
& 3.910 & -0.470 & 0.067 & 3.335 & -0.852 & 1.057 \\
Size & $-0.058^{* * *}$ & $-0.111^{* * *}$ & $-0.023^{*}$ & $-0.088^{* * *}$ & $-0.127^{* * *}$ & $-0.056^{* * *}$ \\
& -9.481 & -6.044 & -1.783 & -14.700 & -7.232 & -4.022 \\
Constant & $1.569 * * *$ & $2.945^{* * *}$ & $0.610^{*}$ & $2.377^{* * *}$ & $3.366^{* * *}$ & $1.490^{* * *}$ \\
& 9.723 & 6.019 & 1.759 & 15.035 & 7.227 & 4.069 \\
\hline Observations & 5,602 & 997 & 1,543 & 5,602 & 997 & 1,543 \\
R-squared & 0.045 & 0.060 & 0.048 & 0.082 & 0.093 & 0.070 \\
\hline
\end{tabular}

Note: The value in parentheses is z-value, and $* * *, * *, *$ means significant at $1 \%, 5 \%$, and $10 \%$ levels, respectively

$<$ Table 4> summarizes the results of the panel regression analysis to look at the effect financial constraints on the firms' investment decision. Model (7) through model (9) use tangible assets growth over total assets and model (10) through model (12) use fixed assets growth over total assets. From model (7) through model (12), the empirical analysis showed the same results in model (1) through model (6), which showed significant positive effects in the relationship between firms' ROA and firms' investment and significant negative effects in the relationship between firm size and firms' investment. So irrespective of firm's financial constraints conditions, profitability (ROA) and firm size are important factor for firm's investment.

Model (8) shows that major shareholders from financially unconstrained firms give significant positive impact on firm's investment. This supports the results of model (2) and model (5). But model (12) shows major shareholders from financially constrained firms also give significant positive impact on firm's investment. In model (9) and model (12), debt from financially constrained firms gave significant negative impact on firm's investment.

Table 4: Test of the Relationship between Financial Constraints and Investment II

\begin{tabular}{ccccccc}
\hline & $(7)$ & $(8)$ & $(9)$ & $(10)$ & $(11)$ & $(12)$ \\
\hline $\begin{array}{c}\text { Dependent } \\
\text { variable } \\
\text { sample }\end{array}$ & All & Unconstrained & Constrained & All & Unconstrained & Constrained \\
\hline M & 0.000 & $0.001^{* *}$ & 0.000 & 0.000 & 0.001 & $0.001^{*}$ \\
& 1.613 & 2.525 & 0.724 & 1.517 & 1.528 & 1.911 \\
Roa & $0.154 * * *$ & $0.131 * * *$ & $0.181 * * *$ & $0.197 * * *$ & $0.115^{* *}$ & $0.450^{* * *}$ \\
& 6.883 & 4.077 & 3.882 & 6.543 & 2.505 & 5.978 \\
Div & 0.093 & 2.343 & $0.552^{* *}$ & 0.362 & $9.628^{* * *}$ & 0.375
\end{tabular}




\begin{tabular}{ccccccc} 
& 0.341 & 0.984 & 2.111 & 0.982 & 2.823 & 0.885 \\
Debt & -0.003 & -0.000 & $-0.038^{* *}$ & $-0.008^{* * *}$ & -0.002 & $-0.115^{* * *}$ \\
& -1.229 & -0.008 & -2.197 & -2.643 & -0.601 & -4.170 \\
Std & 0.023 & $-0.104^{*}$ & -0.012 & 0.015 & $-0.145^{*}$ & 0.014 \\
& 1.058 & -1.798 & -0.158 & 0.526 & -1.755 & 0.107 \\
Size & $-0.067^{* * *}$ & $-0.102^{* * *}$ & $-0.017^{* * *}$ & $-0.109^{* * *}$ & $-0.156^{* * *}$ & $-0.041^{* * *}$ \\
& -14.398 & -7.032 & -2.975 & -17.381 & -7.526 & -4.434 \\
Constant & $1.767 * * *$ & $2.682^{* * *}$ & $0.443^{* * *}$ & $2.897 * * *$ & $4.140^{* * *}$ & $1.075^{* * *}$ \\
& 14.435 & 6.951 & 2.940 & 17.547 & 7.492 & 4.409 \\
\hline Observations & 5,602 & 997 & 1,543 & 5,602 & 997 & 1,543 \\
R-squared & 0.051 & 0.077 & 0.035 & 0.069 & 0.079 & 0.062 \\
\hline Note & & &
\end{tabular}

Note: The value in parentheses is z-value, and ***,**,* means significant at $1 \%, 5 \%$, and $10 \%$ levels, respectively

\section{Conclusion}

This study analyzed what factors contributes to firms' investments for firms listed on the Korea Stock Exchange's securities whose closing month is December from 2001 to 2018 by applying panel regression. The empirical results showed that firstly, significant positive effects in the relationship between firms' ROA and firms' investment and significant negative effects in the relationship between firm size and firms' investment. So irrespective of firm's financial constraints conditions, profitability (ROA) and firm size are important factor for firm's investment. Secondly, major shareholders from financially unconstrained firms give significant positive impact on firm's investment, which support the literature that in financially constrained firms, financial constraints itself rule company, but in financially unconstrained firms, corporate mechanism controls investment decisions (Ra \& Lee, 2012). Thirdly the results show that positive negative impact of debt to investments. This shows that firms cannot invest more under financially constrained condition. Transparency and anti-corruption disclosure of corporate governance are important (Saparovna \& Sayatovna, 2014; Yin \& Zhang, 2019). There is a linear relationship between multinationality and performance ( $\mathrm{Wu} \& \mathrm{He}, 2019$. Shao and $\mathrm{Yu}$ (2016) found that intertemporal endogeneity exists among ownership, investment, and performance through the application of system dynamic equations, which implies that the relationship among ownership structure, investment, and firm performance is dynamic by nature. Yijayakumaran and Vijayakumaran (2019) found that Chinese government's ownership reforms have been successful in terms of providing incentive to managers through managerial shareholdings to take risky financial choices. So we should test the relationship between investment and corporate governance in detail under financial constraints for further study. 


\section{References}

Han, J., H., \& Jeong, S., J. (2013). An integrated decision making model for shipping operation and investment considering the financial constraints. Journal of shipping and logistics, 76(1), 5-28.

Ihm, B., K., Sohn, P., D., \& Kam, D., S. (2011). How does the value of cash holdings affect firm value and investment under financial constraint. The Korean Journal of Financial Engineering, 10(2), 75-98.

Kang, S. (2019). The role of corporate governance in financially constrained firms. Journals of Economics, Marketing \& Management, 7(3), 33-49.

Lau, W. T., \& Mahat, F. B. (2019). Robustness of cash flow value: investment in ASEAN. Journal of Asian Finance, Economics and Business, 6(2), 247-255

Lee, C., H., \& Byun, J. C. (2017). A positive side of financial constraints in cash management. Korean Journal of Financial Management, 34(2), 113-141.

Lee, B. J., \& Kim, D. C. (2017). The effect of financial constraints on stock returns in Korea. The Korean Journal of Finance Association, 30(4), 395-432.

Muhammad, H., Rehman, A., \& Waqas, M. (2016). The effect of corporate governance practices on firm performance: evidence from Pakistan. The East Asian Journal of Business Management, 6(1), 5-12.

Nam, H. J. \& Park, C. G. (2015). Cash holdings and R\&D persistency of the financially constrained firms considering financing frictions. Korean Journal of Financial Engineering, 14(2), 133-155.

Ra, Y. S., \& Lee, Y. G. (2010). Influences of financial constraints on corporate financial structure. Korea Journal of Business Administration, 25(3), 1439-1460.

Rahman, M., \& Khatun, N. (2017). A comparative analysis of corporate governance guidelines: Bangladesh perspective. East Asian Journal of Business Management, 7(2), 5-16.

Ruonan, Z., \& Hong, Y. (2019). Corporate social responsibility disclosure, financing constraints and investmentcash flow sensitivity. East Asian Journal of Business Management, 9(1), 21-28.

Saparovna, M. K., \& Sayatovna, S. M. (2014). Features of corporate governance in Kazakhstan. East Asian Journal of Business Management, 5(2), 15-22.

Shao, L., \& Yu, X. (2015). Empirical study of dynamic corporate governance: new evidence from chinese-listed SMEs. International Journal of Industrial Distribution \& Business, 6(4), 27-37.

Shao, L., Zhang, Li., \& Yu, X. (2017). Empirical study of dynamic Chinese corporate governance based on Chineselisted firms with a panel VAR approach. International Journal of Industrial Distribution \& Business, 8(1), 5-13.

Shin, M. S., Kim, S. E., \& Lee, J. I. (2013). The effects of financial constraints on the marginal value of cash. Journal of Finance and Knowledge Studies, 11(2), 31-66.

Vu, V. T., Do, N. H., Dang, H. N., \& Nguyen, T. N. (2019). Profitability and the distance to default: evidence from Vietnam securities market. Journal of Asian Finance, Economics and Business, 6(4), 53-63.

Wu, R., \& He, Y. (2019). A study on the relationship between multinationality and performance: evidence from China's firms. International Journal of Industrial Distribution \& Business, 10(7), 7-16.

Yijayakumaran, S., \& Vijayakumaran, R. (2019). Debt maturity and the effects of growth opportunities and liquidity risk on leverage: evidence from Chinese listed companies. Journal of Asian Finance, Economics and Business, $6(3), 27-40$.

Yijayakumaran, S., \& Vijayakumaran, R. (2019). Corporate governance and capital structure decisions: evidence from Chinese listed companies. Journal of Asian Finance, Economics and Business, 6(3), 67-79.

Yin, H., \& Zhang, R. (2019). Determinants of corporate anti-corruption practice disclosure: evidence from Chinese firms. International Journal of Industrial Distribution \& Business, 10(3), 7-16.

Zhang, R., \& Yin, H. (2018). Regional financial development, firm heterogeneity and investment efficiency. Journal of Asian Finance, Economics and Business, 5(4), 73-83. 